\title{
A Comparative Analysis of Public Education System of Indonesia and Uzbekistan
}

\author{
Jakhongir Shaturaev \\ Department of "Corporate Economics and Business Analysis", \\ Tashkent State University of Economics, Tashkent, Uzbekistan
}

\section{ABSTRACT}

The Government of Uzbekistan, experiencing modern reforms in an educational sector as a strategic part of a development program after the last presidential elections, spends an enormous portion of its resources on public education - significantly more than other countries in Central Asia, elsewhere with a similar income level, however, satisfactory results yet to be achieved and remains one of the crucial issues of the republic. Meanwhile, far in South-East Asia, Indonesia has made dramatic progress on expanding access to education, directing a huge stream of money towards formal education over the past few decades, but still, the learning outcomes remain low. In addition to key reforms in mandatory schooling in terms of increased quality of investment, utilization of information, communications hold considerable promise in improving educational outcomes. This comparative study on the compulsory education of both countries investigates the reasons for the low results in schooling in Indonesia and Uzbekistan. Throughout the survey, we have interviewed school teachers, principals, and authorities, analyzing available sources to find out the problem-causing factors. Drawing on our findings indicating the need for reforming the teaching-learning process, and proper investments in public education to reach promising milestones.

KEY WORDS: PUBLIC EDUCATION; PRIMARY SCHOOLS; FINANCING EDUCATION; EDUCATIONAL ISSUES; INDONESIA; UZBEKISTAN; SOUTHEAST ASIA; CENTRAL ASIA.

\section{INTRODUCTION}

Humanity is facing the greatest challenge since World War Two as it has weathered the global financial and economic crisis well, certainly better than many economies at its level of development in some regions. The covid-19 has affected people regardless of nationality, income, or even gender. Education is no exception. In such a case, this challenge has touched longstanding scars on the educational system of Indonesia and Uzbekistan.

Biosc Biotech Res Comm P-ISSN: 0974-6455 E-ISSN: 2321-4007

\section{crossef}

Identifiers and Pagination

Year: 2021 Vol: 14 No (5) Special Issue

Pages: 89-92

This is an open access article under Creative

Commons License Attribn 4.0 Intl (CC-BY).

DOI: $h t t p: / / d x . d o i . o r g / 10.21786 / b b r c / 14.5 / 18$

\section{Article Information}

Received: $15^{\text {th }}$ Jan 2021

Accepted after revision: $28^{\text {th }}$ Mar 2021
The main obstacle, however, of human development in Uzbekistan lies in the development of skilled and knowledgeable personnel who can facilitate the transition to an internationally competitive economy and education. The availability of quality human resources is critical in effecting this transformation. The government, with the assistance of Asia Development Bank (ADB) and other development partners, is seeking to accelerate this transformation. Uzbekistan's education spending as a share of GDP is one of the highest in the world. Government education spending amounted to 5.4 percent of GDP in 2017 and 5.9 percent in 2018, more than in Kazakhstan, Russia, Turkey, countries with similar incomes, regional peers, and the OECD (Organization for Economic Co-operation and Development) (Izvorski et al. 2019). Ensuring the efficiency, effectiveness, and sustainability of such high investment in education is a challenge for the country's fragile economy. 
Indonesia has made significant improvements in its education sector over the past 15 years through major reforms. In particular, gains have been made in terms of improving access to education, as well as educational attainment (The World Bank 2017). Despite these gains, however, Indonesia still lags behind many regional peers in terms of student learning - based on Program for International Student Assessment (PISA) 2018 scores, only 30 percent of students met the most basic level of literacy proficiency (OECD 2019). Indonesia lags behind many emerging market peers in terms of spending and learning outcomes as measured by global benchmarks such as PISA scores (Figure 1).

Such low levels of sector productivity are concerning, especially when the Government of Indonesia (GoI) has a legal mandate to spend 20 percent of its budget on the education sector (Bhardwaj, Yarrow, and Cali 2020). While the Indonesian mandate may appear to be a very large amount, when expressed in terms of the share of GDP, Indonesia lags behind its regional peers in public education spending (Figure 2). This an effect primarily of low levels of tax collection, which is expected to worsen during the COVID crisis, however, the Minister of Education and Culture (Mendikbud) Nadiem Makarim has allowed local governments to open schools or carry out face-to-face learning activities starting January 2021. The opening of these schools is no longer based on zoning for the spread of COVID-19.

\section{Background}

Education in Indonesia: Indonesia, home to more than 275 million people, is the fourth most populous country in the world. It is also the largest archipelago on the globe. Its territory spans more than 17,000 islands that stretch for 3,181 miles along the equator between the Pacific and Indian Oceans (Worldometer 2020). After independence in 1945, Indonesia constitutionally enshrined education as a right of all Indonesian citizens and sought to establish a more egalitarian and inclusive mass education system. Although public education is mostly secular and Indonesia is formally a secular state, Islamic education is highly prominent in Indonesia's large private education sector. The massive 29 million member-strong Islamic organization Muhammadiyah (followers of Muhammad), for instance, currently operates 172 universities, some 2,600 elementary schools, and close to 3,000 secondary schools throughout Indonesia. These institutions teach a secular, general academic curriculum in addition to religious studies.

The Republic of Indonesia runs a 6-3-3 for public education structure. Indonesia's education system comprises four levels of education: primary (grades 1-6), junior secondary (grades 7-9), senior secondary (grades 10-12), and higher education. The first two levels constitute 'basic education' as that term is used in the Indonesian context (Shaturaev 2014). State educational institutions dominate the education system, particularly at primary and junior secondary levels. However, the private sector also plays a significant role, accounting for around 48 percent of all schools, 31 percent of all students, and 38 percent of all teachers. It also accounts for 96 percent of all HEIs and almost 63 percent of higher education enrolments.

The state educational system is mostly non-sectarian although it includes some religious (typically but not only Islamic) schools and HEIs. The private educational system, by contrast, is dominated by religiously oriented schools and HEIs, in particular, those associated with Indonesia's two major Islamic social organizations, Muhammadiyah and Nahdlatul Ulama, although it also includes non-religious commercially oriented institutions especially in higher education. Generally, state educational institutions are considered to be of higher quality than private educational institutions although there is great variation among both public and private institutions (Suryadarma and Jones 2013).

Education In Uzbekistan: In 2017, education reforms in Uzbekistan changed from a 12-year program to 11 years after a previous reform disappointed and troubled parents and children. Eleven years of primary and secondary education are obligatory, starting at age seven. The rate of attendance in those grades is high, although the figure is significantly lower in rural areas than in urban centers. Preschool registration has decreased significantly since 1991. The official literacy rate is 99 percent. However, in the post-Soviet era educational standards have fallen. Funding and training have not been sufficient to effectively educate the expanding younger cohorts of the population.

Between 1992 and 2004, government spending on education dropped from 12 percent to 6.3 percent of gross domestic product. In 2006 education's share of the budget increased to 8.1percent. Lack of budgetary support has been more noticeable at the primary and secondary levels, as the government has continued to subsidize university students. Between 1992 and 2001, university attendance dropped from 19 percent of the college-age population to 6.4 percent. The three largest of Uzbekistan's 63 institutions of higher learning are in Nukus, Samarkand, and Tashkent, with all three being state-funded. Private schools are forbidden as a result of a government crackdown on the establishment of Islamic fundamentalist (Wahhabi) schools. However, in 1999 the government-supported Tashkent Islamic University was founded for the teaching of Islam (Shaturaev 2014).

Approximately 60 percent of Uzbekistan's population is covered under the system of education. The earlier educational system required 11 years of compulsory schooling for both men and women. In 1992 the policy decision was made to change from 11 to 9 years of compulsory education. After nine years of compulsory schooling, students can prepare for higher education in tenth or eleventh grade or turn to vocational training. After graduating from any type of secondary education, an individual can enter a higher education institution to obtain a bachelor's degree and continue study toward a master's or doctoral degree (Shaturaev 2014). 
As of January 2007, there were 1,055 new secondary specialized vocational educational establishments, including 99 academic lyceums and 953 vocational colleges. Of these vocational colleges, 296 were housed in newly constructed buildings, and 628 were housed in the buildings of former vocational schools having undergone major reconstruction including equipping them with modern teaching materials and laboratories. Secondary specialized vocational educational establishments enrolled 1,075,000 students, out of which 1,021,900 students (164,400 after the grade 11) enrolled in 953 vocational colleges and 53,100 students enrolled in 99 academic lyceums (Niyozov and Dastambuev 2013).

\section{CONCLUSION}

To conclude the result of the study, the researcher will discuss based on the research questions as proposed in chapter I section 1.4. There are four specific research questions and one general research question, which underpinned this study. All of them, in this part, will be reasserted and it will be followed by its explanation and description to answer the problems being raised. Based on the analysis data got from questionnaires, classroom observation, interview data, and data gathering. Some conclusions can be presented. First, related to the first research question i.e. "What kind of policies do Indonesia and Uzbekistan run in their primary education?" The data showed that there is a significant difference between the Primary Education System of Indonesia and Uzbekistan. The Republic of Indonesia runs a 6-3-3 formal education structure. (UNESCO IBE, World Data on Education. 7th Edition, 2010-2011) Meanwhile, Uzbekistan runs a 4-5-3 formal education structure. (Seitkhalilov et al. 2002) Another difference in basic education level between the two countries is that Education System is decentralized in Indonesia, simultaneously, it remains centralized, but the management of education is still decentralized in Uzbekistan.

However, there are some similarities in primary education in both countries as well. For instance, compulsory education is free. According to the Indonesia FBE (Free Basic Education) policy, school fees are to be abolished in primary and junior secondary schools. It is proved with the Law on Education of the Republic of Uzbekistan (Article 4), adopted on 29 August 1997 (No.464). Second, regarding the second research question: "What are the current problems in primary education in both countries?" the data from the questionnaires given to the 4 observed elementary schools pupils, teacher interviews, and other collected data show that there are enough problems in basic education level in both countries. There are the same problems in each country, like dropouts (Indonesia was 20.0\%, male 22.6\%, and female 17.2\% for the school year ending in 2010, while in Uzbekistan total number was $1.9 \%$, respectively, male $2.2 \%$, and female $1.7 \%$ for the school year ending in 2010), lack of quality teachers, lack of teaching tools, and books and missing modern teaching tools in rural areas.
Therefore, it can be concluded, based on the school observation that Primary Education in Indonesia and Uzbekistan have to take some extra effort to improve and reach high results. Third, the researcher has looked for an answer to the third research question "What kind of teaching methods are used by primary school teachers in both countries?" The data showed that in Indonesia, nowadays, according to school observation, teacher-centered class instruction has changed into student-centered instruction. In the elementary school of Uzbekistan starting from 2012 according to President Decree No 1875 December 2012, the teacher-centered system changed into a student-centered system. It means that this policy requires students to be much active, $70 \%$ of speech in the classroom should be by students while 30\% by the teacher (Shaturaev 2019). The teaching methods in urban schools are the same in both countries, by using modern teaching devices both countries are reaching quite high expectations.

In outlying areas, it remains a crucial issue in either Indonesia or Uzbekistan. Finally, the fourth specific research question is "How is the classroom arrangement and management in both countries' primary schools?" Collected data and images show that there is a significant difference between schools in Indonesia. SDN Sukawarna 2 and SDN Banjasari differ one from another in terms of classroom arrangement and managements almost same. SDN Banjarsari is equipped with the latest teaching devices while in SDN Sukawarna 2 these kinds of tools are missing. (See Appendix 0) The Uzbek school No 291, which is located in Tashkent city, one can meet the latest teaching-learning tools, and the class condition is in a good look. In Tesha Saydaliev school No 2 there are no new teaching gadgets, but still owning teaching aids. To summarize, nevertheless, some crucial issues remain, such as lack of quality teachers, dropouts, access to education in outlying areas, and supplying books and proving teacher-learning gadgets. There are, however, some reformations being taken and new policies have been introduced in both countries to improve quality of education, teacher effectiveness, access to education, and teacher pieces of training, and these efforts will pay off soon for either Indonesia or Uzbekistan.

\section{REFERENCES}

Bank, T. W., \&t The World Bank. (2010). Trends in Maternal Mortality : 1990 to 2010. Organization.

Bhardwaj, R., Yarrow, N., \&t Cali, M. (2020). EdTech in Indonesia. In EdTech in Indonesia. https://doi. org/10.1596/33762

Dharma, S. (2008). Strategi Pembelajran dan Pemilihannya. Antimicrobial Agents and Chemotherapy.

Eric, R. (2019). Education in Indonesia. Asia Pacific,Asia Pacific,Credential Evaluation Issues,Education Policy,Education System Profiles.

Heyward, M., \& Sopantini. (2014). Indonesia: The Challenges of Quality and Equity in Education. In Education in South-East Asia. https://doi. org/10.5040/9781472544469.ch-004

Indra, H. (2016). Pendidikan Tinggi Islam Dan Peradaban 
Indonesia. Al-Tahrir: Jurnal Pemikiran Islam. https:// doi.org/10.21154/al-tahrir.v16i1.317

Izvorski, I. V., Trushin, E., Appiah-Koranteng, A., Varoudakis, A., Islam, R., Safarov, M., Lord, D., Motohashi, M., Ihsan, A., Zorya, S., Hawkesworth, I., Philipsen, F., James, S., Anadolu, E., Teixeira, J., \&t Karakulah, K. (2019). Uzbekistan Public Expenditure Review. In Uzbekistan Public Expenditure Review. https://doi.org/10.1596/33371

Mada, universitas G. (1945). Undang-undang Dasar RI Tahun 1945.

Ministry of National Development. (2010). Report on The Achievement of The Millennium Development Goals Indonesia 2010. In Chemistry \& ....

Niyozov, S., \& Dastambuev, N. (2013). Exploiting globalization while being exploited by it:Insights from post-Soviet education reforms in Central Asia. Comparative and International Education. https://doi. org/10.5206/cie-eci.v41i3.9210

OECD. (2019). PISA 2018 Results. In OECD Publishing. OECD, \& ADB. (2015). Education in Indonesia: Rising to the Challenge. In Far Eastern Survey.

OECD Publishing. (2016). PISA 2015 Assessment and Analytical Framework: Science, Reading, Mathematic and Financial Literacy,. In OECD Publishing.

Oxford Business Group. (2020). The impact of Covid-
19 on global supply chains. Covid-19 Economic Assessments.

Shaturaev, J. (2014). Comparative study on similarities and differences of teaching and learning process in primary schools in Indonesia and Uzbekistan (1st ed.) [Repository Universitas Pendidikan Indonesia]. https:// doi.org/10.13140/RG.2.2.25852.28806

Shaturaev, J. (2019). The Importance of Handwriting in Education. International Journal of Advanced Research, 7(12), 947-954. https://doi.org/10.21474/ijar01/10237 Suryadarma, D., \&t Jones, G. W. (2013). Education in Indonesia. In Education in Indonesia. https://doi. org/10.4324/9780429397981-5

The World Bank. (2017). Enterprise Surveys Indicator Descriptions. In The World Bank Group.

UNESCO. (2010). World Data on Education. Wde.

UNESCO Global Monitoring Report. (2014). Global Monitoring Report 2013/4: Teaching and Learning: Achieving quality for all. In United Nations Educational Scientific and Cultural Organization.

World Development Indicators 2016. (2016). In World Development Indicators 2016. https://doi. org/10.1596/978-1-4648-0683-4

Worldometer. (2020). World Population Clock: 7.8 Billion People (2020) - Worldometer. World Population Clock. 